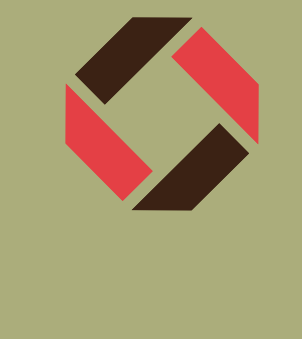

\section{Alta Devices moves out of the lab and into the valley}

\section{Jessica M. Smith}

$\mathbf{I}^{\mathrm{n}}$ n the world of technology start-ups, especially clean energy, "the valley"-also known as "the valley of death" - refers to the gap in capital between the funding of invention - through government grants and venture capitaland mass production. Recently, the thinfilm solar-cell manufacturer Solyndra famously failed to cross this valley, declaring bankruptcy after accepting millions of dollars in US government gap funding. The controversy around this particular case, and around the fate of many solar start-ups generally, means that all eyes are on Alta Devices. As the start-up begins production on its pilot line, the clean energy community will watch as Alta Devices attempts to take its technology out of the lab and into the valley.

Alta Devices was founded by Harry Atwater of the California Institute of Technology and Eli Yablonovic of the University of California-Berkeley in collaboration with venture capitalist Andy Rappaport. The company relies on Yablonovic's research in the 1980s on a technique called epitaxial liftoff. The active layer Alta Devices uses in solar cells, gallium arsenide (GaAs), can be produced inexpensively using this technique without degrading the performance of the cell. The team began the company in 2007 , and has subsequently worked toward perfecting epitaxial liftoff of GaAs at a laboratory scale. When the pilot production line opens later this year, this invention will be produced for the first time on large scale.

Epitaxial liftoff is an efficient way to create thin wafers of GaAs. On top of a high-purity GaAs surface, layers of GaAs are deposited with alternating layers of aluminum arsenide (AlAs). "We take advantage of the serendipitous fact that the etch selectivity between AlAs and GaAs is more than 100 million, so that it's possible to immerse the structure in an etching solution and remove the AlAs layer completely without etching the GaAs layer," said Atwater. The free GaAs wafers are of very high purity, and the original GaAs surface can be used again to create more wafers.

Solar cells made from these GaAs wafers compare favorably to conventional silicon photovoltaic (PV) cells. The highest performing silicon PV cells are made out of high-purity silicon, similar to that found in computer chips, which allows them to reach solar conversion efficiencies near $30 \%$. The silicon used in these cells, however, is costly to produce, and the cells require a thick layer in order to reach maximum efficiency.
Gallium arsenide PV cells made through epitaxial liftoff can also reach high efficiency-currently $23.4 \%$ and climbing. Because of the properties of GaAs, efficient solar cells can be made with a much thinner layer of material. Combined with the less expensive processing method, Alta Devices' solar cells can be made for a fraction of the cost of silicon PV cells.

The conventional wisdom of the photovoltaics community is that any solar cell that is inexpensive to produce must also have a low efficiency. For instance, polymer PV cells, or those made with amorphous cadmium telluride, have efficiencies below $10 \%$. As a result, any cost efficiency is mitigated by the small amount of electricity that will come out of one of these solar cells. Through epitaxial liftoff, Alta Devices' gallium arsenide solar cells can be both highly efficient and inexpensive.

Alta Devices is working toward further increasing the efficiency of their solar cells. Atwater said, "We see 30\% [efficiency] as an achievable limit. That was seen as a lunatic idea when we began the company."

Rappaport agreed, adding, "Fortunately, you found a lunatic.” Rappaport

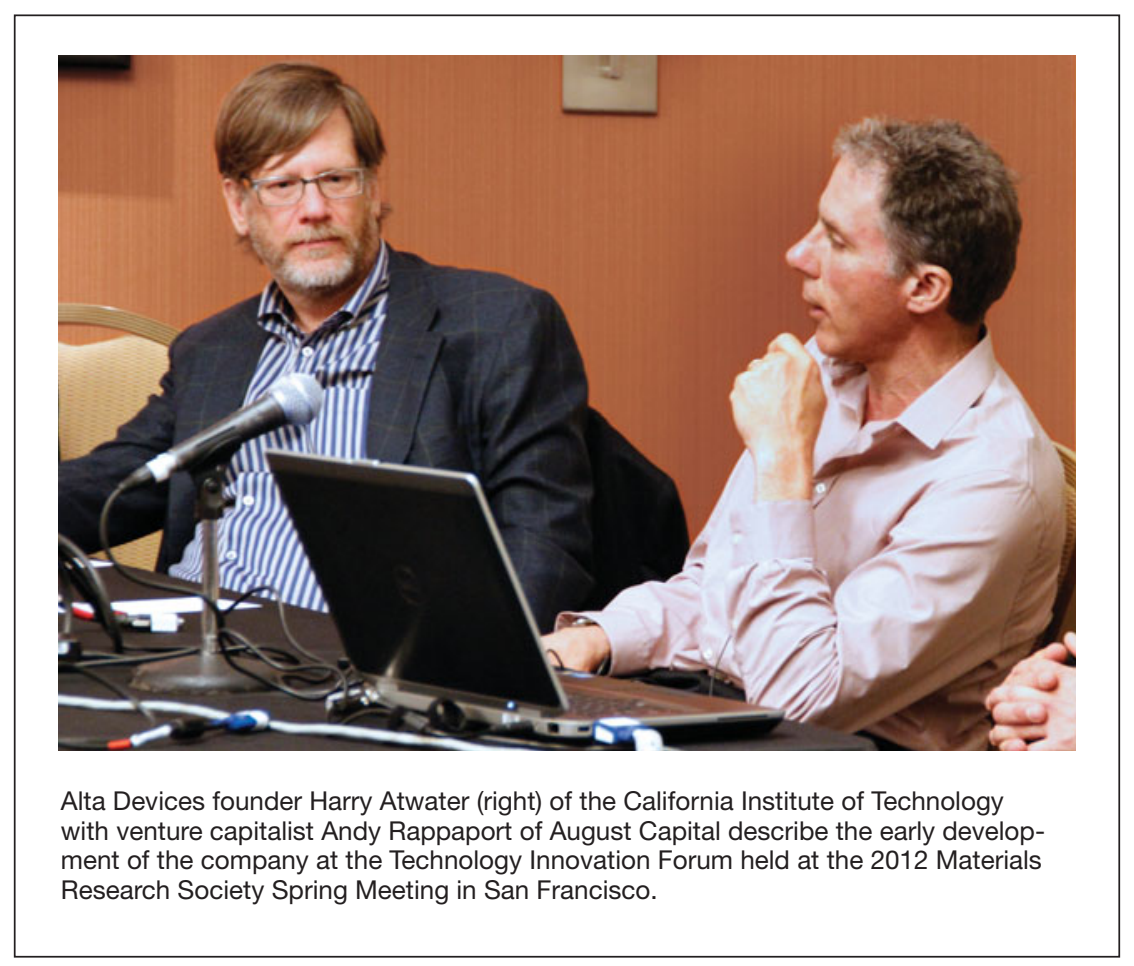


had never invested in a clean energy company before and said he is unlikely to invest in one again. "A problem with solar start-ups is that most of the innovation is around production methods at scale. It's expensive to get to scale!" he said. He liked Alta Devices because it was the first solar company he had seen that was fundamentally different. "The cost-efficiency curve had gotten to be conventional wisdom." That Alta Devices had a way to deviate from the cost-efficiency curve convinced Rappaport and became the foundation of the company.

Alta Devices' leaders believe that they can find a market for their solar cells soon after they optimize the pilot line. They said their thin, flexible, highefficiency panels will be ideal for aerospace and military applications in which the right combination of properties is more important than cost for a PV cell. These customers will give the company time to decrease manufacturing costs, according to Rappaport. "When we are far down the learning curve, we should be as cheap, or cheaper, than anything else out there. Eventually, we should be the best solution to utility scale solar, but we don't have to immediately transport ourselves to the end of the learning curve. We get to gradually get there."

At the same time, another early application for a flexible, high-efficiency solar cell could be implemented in developing countries. "Worldwide energy

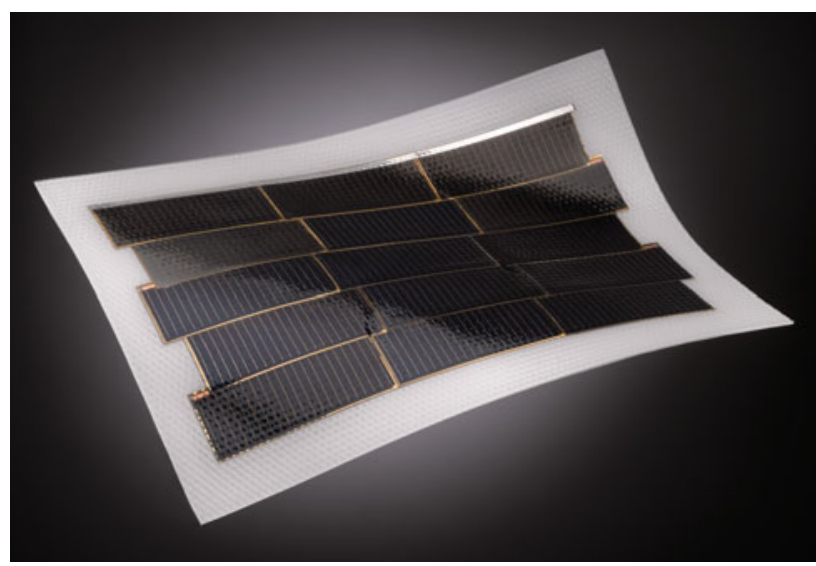

Alta Devices' GaAs high-efficiency, ultrathin solar panel.

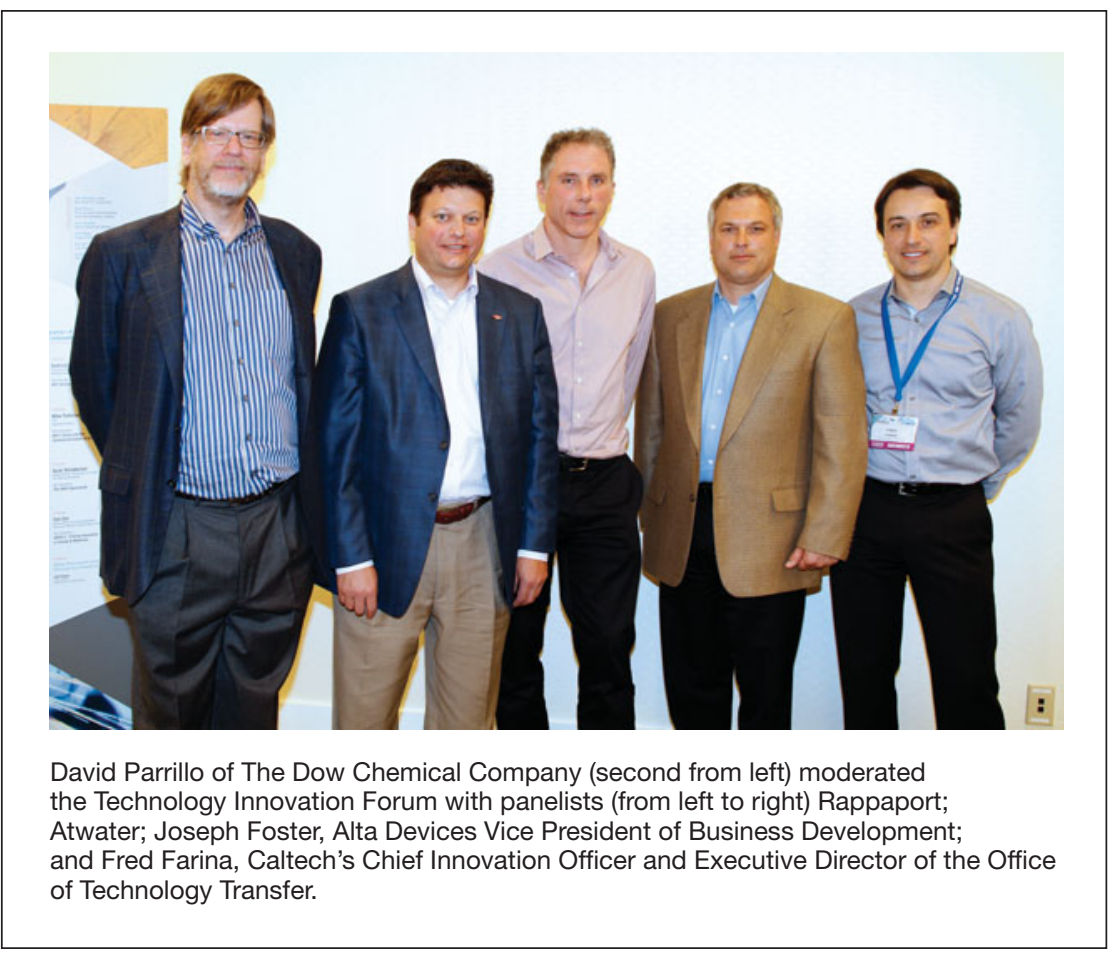

production and consumption has been hampered in a very general way because of the high infrastructure cost of distribution. If you're able to generate power locally, you reduce the dependence on expensive, difficult-to-construct distribution systems. We're building something lightweight, portable, and cheap, so we're contributing to a notion of local power generation." Rappaport said that the same properties that allow the Alta Devices' solar cells to be useful to military operations could also be useful in places that lack energy infrastructure.

To be used in other countries, particularly in Europe, the solar cells may need to be part of a recycling scheme because of the countries' strict regulations with respect to toxic materials. For instance, the Restriction of Hazardous Substances Directive, a policy of the European Union, bans cadmium in all consumer products. To receive permission to sell panels in the European Union, First Solar, which makes cadmium telluride solar cells, had to agree to remit all of the panels back to their factory in Arizona at the end of life. "People regarded that as being a significant liability," Atwater said, referring to the high insurance costs to First Solar. "They're profitable even doing this recycling. They're heading off the criticism that they will leave the world with an environmental obligation if they go bankrupt."

In Alta Devices, the toxic element of concern is arsenide. Atwater said that, increasingly, solar companies do recycle part of their solar cells. He said, "I imagine Alta will follow suit as a responsible corporate citizen."

Given the challenges facing solar startups, considering a recycling policy before launching a pilot line may seem optimistic. Luckily, the founders of Alta Devices seem to overflow with optimism that they have discerned the right combination of technology and business strategy. Despite these assets, to land on the other side of "the valley of death" as a solar company that manufactures a new material will be a significant accomplishment. 


\section{Univaled Ens for TEM}

\section{$0.98 \mathrm{sr} 100 \mathrm{~mm}^{2}$}

- Exponentially enhances elemental mapping for nano-area analysis TEM

- Automatic retractable design
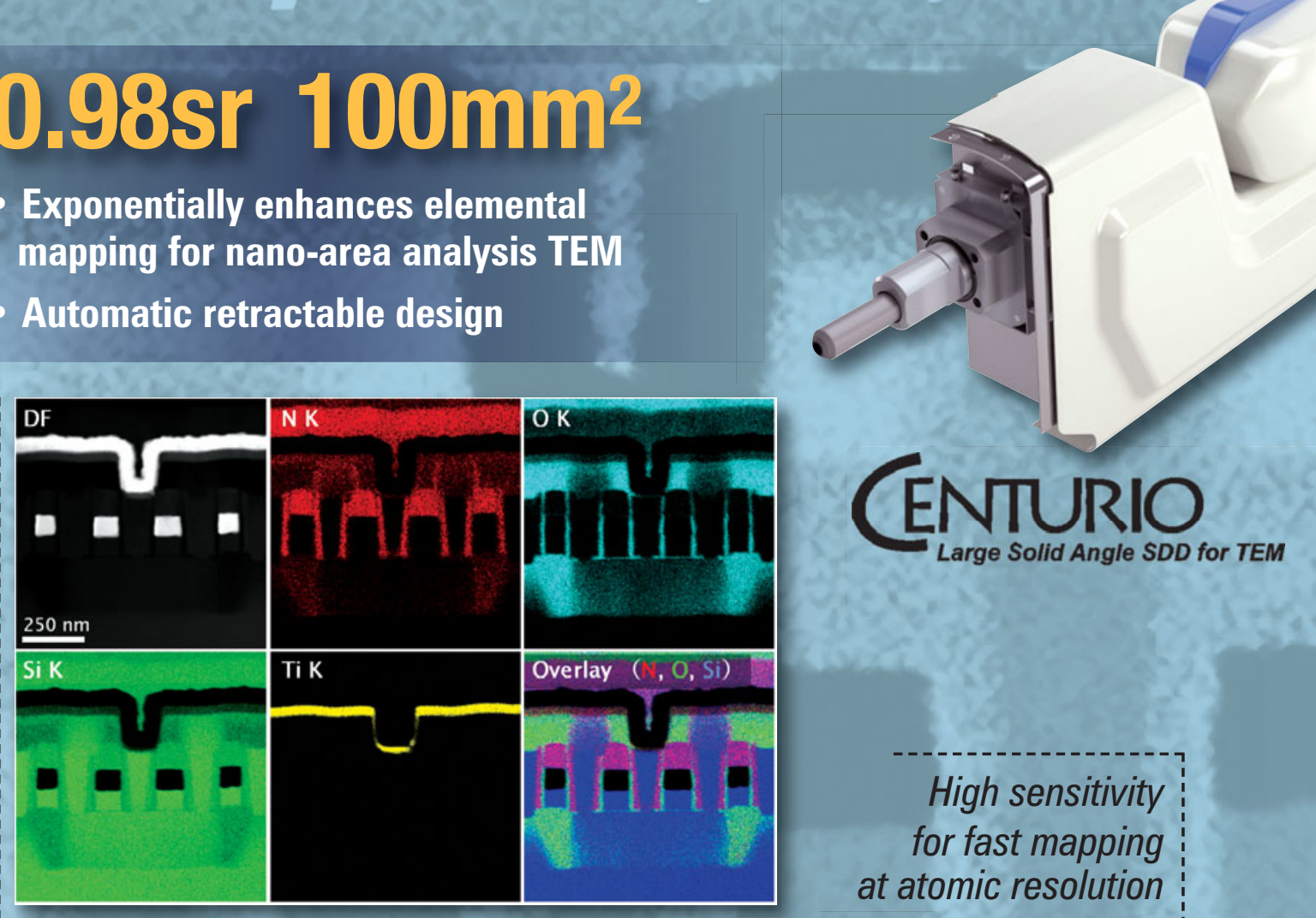

Seamless chemical mapping and data collection for S/TEM-TEMSEM-EDS. $(256 \times 256$ pixels.

Total acquisition time: 1 min. $13 \mathrm{sec}$.)

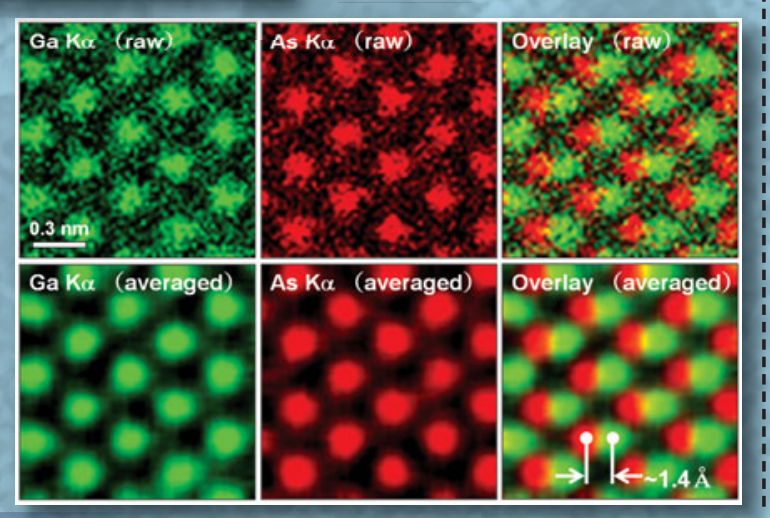

High sensitivity for fast mapping at atomic resolution L-1

\section{Vlew our real-time}

\section{DRAM analysis video}

at WWW.jeolusa.com/UnrivaledEDS

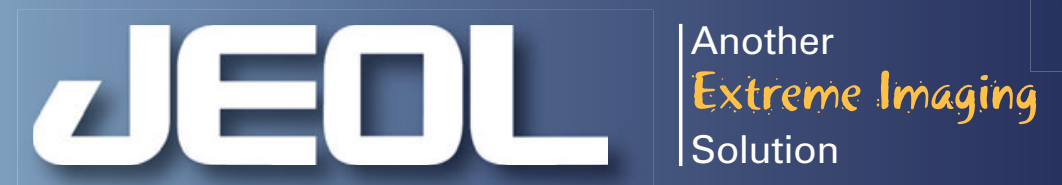

Global Solutions Provider for Advanced Technology www.jeolusa.com•salesinfo@jeol.com 978-535-5900

Find us on Facebook and Twitter @jeolusa

JEM-2800

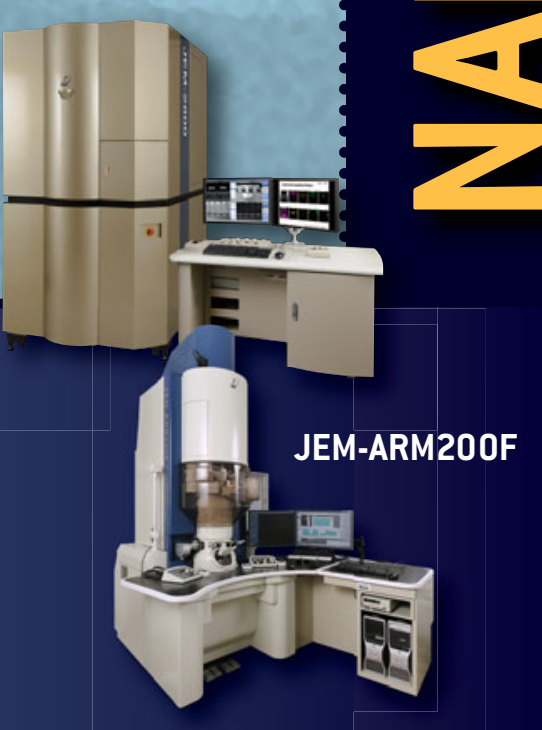

